\title{
Correction to: Attenuated expression of SNF5 facilitates progression of bladder cancer via STAT3 activation
}

\author{
Hua Ding ${ }^{1}$, Yaqin Huang ${ }^{2}$, Jiazhong Shi ${ }^{2}$, Liwei Wang ${ }^{1,3}$, Sha Liu² ${ }^{2}$ Baixiong Zhao ${ }^{1}$, Yuting Liu ${ }^{2}$, Jin Yang ${ }^{2^{*}}$ and \\ Zhiwen Chen ${ }^{1 *}$ (1)
}

\section{Correction to: Cancer Cell International (2021) 21:655 https://doi.org/10.1186/s12935-021-02363-3}

In this article [1], the author would like to update the Funding section as below and the description in Fig. 7 has been added with this correction.

1. Funding section should be: This study was supported by the National Natural Science Foundation of China (Grants 81772738, 81572772, 81602250) and Key Talents Support Plan of Army Medical University (2019, 410301053410).

2. Figure 7 legend should be added: ${ }^{*} p<0.05,{ }^{* * *} p<0.01$, **** $p<0.001$.
Accepted: 30 December 2021

Published online: 14 January 2022

\section{Reference}

1. Ding H, Huang Y, Shi J, Wang L, Liu S, Zhao B, Liu Y, Yang J, Chen Z. Attenuated expression of SNF5 facilitates progression of bladder cancer via STAT3 activation. Cancer Cell Int. 2021;21:655. https://doi.org/10.1186/ s12935-021-02363-3.

\section{Publisher's Note}

Springer Nature remains neutral with regard to jurisdictional claims in published maps and institutional affiliations.

\section{Author details}

'Department of Urology, Southwest Hospital, Third Military Medical University (Army Medical University), Chongqing 400038, China. ${ }^{2}$ Department of Cell Biology, Third Military Medical University (Army Medical University), Chongqing 400038, China. ${ }^{3}$ Unit 32357 of People's Liberation Army, Pujiang 611630, China. original author(s) and the source, provide a link to the Creative Commons licence, and indicate if changes were made. The images or other third party material in this article are included in the article's Creative Commons licence, unless indicated otherwise in a credit line to the material. If material is not included in the article's Creative Commons licence and your intended use is not permitted by statutory regulation or exceeds the permitted use, you will need to obtain permission directly from the copyright holder. To view a copy of this licence, visit http://creativecommons.org/licenses/by/4.0/. The Creative Commons Public Domain Dedication waiver (http://creativeco mmons.org/publicdomain/zero/1.0/) applies to the data made available in this article, unless otherwise stated in a credit line to the data. 